\title{
The role of tax competition between the countries of the world and the features of determining the main tax competitors of Ukraine among the European countries
}

\author{
Anton Boiko
}

Ph.D., Associate Professor, Economic Cybernetics Department, Sumy State University, Ukraine

Iaryna Samusevych

Ph.D., Assistant, Department of Accounting and Taxation, Sumy State University, Ukraine

\begin{abstract}
The article defines the role of the tax system, which it plays to gain competitive advantages of the country in social and economic spheres. The system of relevant taxes, characterizing the level of competition of the national tax system, is identified. Methodological basis for determining tax countries competing with Ukraine based on the cluster analysis is improved. By implementing the algorithm for establishment the European countries - tax competitors of Ukraine, firstly, potential tax competitors of Ukraine were identified, secondly, real tax competitors of Ukraine in a cluster with a similar structure of the tax system in terms of socioeconomic development were set.
\end{abstract}

Keywords: tax competition, cluster analysis, socio-economic development, capital, labor power.

JEL Classification: C38, H20.

\section{Introduction}

At the present stage of the international integration of economic relations the tax systems of countries are developing not only under the influence of internal goals of state policy, but also taking into account the global trends. That is why the stage of developing a strategy for reforming the country's national tax system in the context of increasing its tax competitiveness should be preceded by the allocation of a range of countries potential tax competitors. This allows identifying similar and distinctive features of the functioning of tax systems to determine the competitive advantages and threats that provide a certain level of tax competition. Given the existence of tax and non-tax effects of tax competition, it is advisable to group the countries - tax competitors considering the specifics of their tax systems, as well as the macroeconomic conditions for their development.

\section{Literature review}

The theory of tax competition begins to grow actively in the second half of the XXth century. It was the beginning of the study of the regional tax competition, conducted by Charles Tiebout [10], who concluded its positive role. The next stage was the development of the theory of international tax competition. The study of the taxation of foreign capital was conducted in the 1960s by G. McDougall [7], P. Richman [8], M. Kemp [6], led to the conclusion that the effectiveness of the tax system of the state in the case of taxation of non-resident capital for the location of the investor as opposed to collecting taxes based on the source of income. The formalization of the theory of regional tax competition performed by J. Zodrov and P. Mietskovski [12] made it possible to demonstrate the effect of capital mobility on the level of tax rates established on income from capital. Further development of tax competition envisaged consideration in the capacity of mobile factors, not only capital, but also labor power, which is observed in the works of D. Wilson and R. Gordon [5], D. Wildasin [11], G. Fernandez [4].

The results of the research of tax impact on the mobility of taxpayers, conducted by H. Blöchliger and J. Pinero-Campos [1], allowed to define the role of individual taxes in determining the tax competitiveness of jurisdiction. The conclusions drawn from the results of calculations made by F. Delgado [3] allowed to argue that the European Union countries are characterized by the convergence of the level and structure of tax revenues, which necessitates further studies of national tax systems from the point of view of identifying countries, most likely to compete for the movement of mobile factors of production due to the similarity of conditions of taxation. 


\section{Results}

Identification of Ukraine's potential tax competitors, between which the mobile objects of taxation are distributed, is expedient to implement on the basis of methods of cluster analysis, which is proposed to be carried out in two stages.

The first stage is the grouping of countries according to the structure of the tax system. At this stage, a sample from 38 European countries that have the closest foreign economic ties, and also are geographically close enough, which corresponds to the general vector of economic and political integration of Ukraine with the countries of the European Union was formed. The input indicators, based on the assessment of the values of which the clusterization is conducted, are five criteria that illustrate the structure of the tax system and the level of tax burden on various types of taxation objects (Table 1).

Table 1. Characteristics of cluster parameters of the region

\begin{tabular}{|l|l|}
\hline \multicolumn{1}{|c|}{ Criterion } & \multicolumn{1}{c|}{ Characteristics } \\
\hline Value Added Tax $(V A T)$ & $\begin{array}{l}\text { The total rate of value added tax, which is subject to the taxation of most goods and } \\
\text { services }\end{array}$ \\
\hline Corporate Income Tax $(C I T)$ & $\begin{array}{l}\text { The general corporate income tax rate (in most countries only the income tax rate is } \\
\text { taken into account) }\end{array}$ \\
\hline $\begin{array}{l}\text { Minimum Tax on Personal Income } \\
\left(T P I_{\min }\right)\end{array}$ & The minimum tax rate on personal income, different from zero, used in the country \\
\hline $\begin{array}{l}\text { Maximum Tax on Personal Income } \\
\left(T P I_{\max }\right)\end{array}$ & $\begin{array}{l}\text { The maximum tax rate on personal income, which is used in the country on income } \\
\text { above a certain level }\end{array}$ \\
\hline Social Insurance $(S I)$ & $\begin{array}{l}\text { The total rate of social security payments paid by employers and employees, expressed } \\
\text { as a percentage of gross salary }\end{array}$ \\
\hline
\end{tabular}

The period of the study was 2013, which is due, firstly, to the availability of full statistical reporting for all countries that form the initial sample, and secondly, the presence of structural deformations in the socioeconomic development of Ukraine from the beginning of 2014, which are not of an economic but of a political nature and military actions. Statistical information in the context of these indicators for the countries studied in the period under review is presented in Table 2. The source of statistical information is the statistical database "Collecting taxes" USAID [2].

Table 2. Indicators characterizing the structure of the tax system in Europe as of 2013

\begin{tabular}{|l|c|c|c|c|c|}
\hline \multicolumn{1}{|c|}{ Country } & $V A T$ & $C I T$ & $T P I_{\min }$ & $T P I_{\max }$ & $S I$ \\
\hline Armenia & 20.00 & 20.00 & 10.00 & 20.00 & 3.00 \\
\hline Austria & 20.00 & 25.00 & 20.44 & 50.00 & 42.35 \\
\hline Azerbaijan & 18.00 & 20.00 & 14.00 & 30.00 & 25.00 \\
\hline Belarus & 20.00 & 24.00 & 12.00 & 12.00 & 12.30 \\
\hline Belgium & 21.00 & 33.99 & 25.00 & 50.00 & 37.84 \\
\hline Bulgaria & 20.00 & 10.00 & 10.00 & 10.00 & 28.90 \\
\hline Croatia & 23.00 & 20.00 & 12.00 & 40.00 & 36.70 \\
\hline Cyprus & 15.00 & 10.00 & 20.00 & 30.00 & 13.60 \\
\hline The Czech Republic & 20.00 & 19.00 & 15.00 & 15.00 & 45.00 \\
\hline Denmark & 25.00 & 25.00 & 3.67 & 51.50 & 2.00 \\
\hline Estonia & 20.00 & 21.00 & 21.00 & 21.00 & 35.90 \\
\hline Finland & 23.00 & 26.00 & 8.50 & 30.00 & 27.48 \\
\hline France & 19.60 & 33.33 & 5.50 & 40.00 & 42.48 \\
\hline Georgia & 18.00 & 15.00 & 20.00 & 20.00 & 25.00 \\
\hline Germany & 19.00 & 15.00 & 15.00 & 45.00 & 38.86 \\
\hline Greece & 19.00 & 24.00 & 15.00 & 40.00 & 33.65 \\
\hline Hungary & 25.00 & 19.00 & 17.00 & 32.00 & 44.00 \\
\hline Ireland & 21.00 & 12.50 & 20.00 & 41.00 & 12.50 \\
\hline Italy & 20.00 & 27.50 & 23.00 & 43.00 & 39.36 \\
\hline Latvia & 21.00 & 15.00 & 26.00 & 26.00 & 33.09 \\
\hline Lithuania & 15.00 & 15.00 & 15.00 & 39.98 \\
\hline
\end{tabular}


Table 2. Indicators characterizing the structure of the tax system in Europe as of 2013

\begin{tabular}{|l|c|c|c|c|c|}
\hline \multicolumn{1}{|c|}{ Country } & $V A T$ & $C I T$ & $T P I_{\min }$ & $T P I_{\max }$ & $S I$ \\
\hline Luxemburg & 15.00 & 21.00 & 8.20 & 38.95 & 23.75 \\
\hline Malta & 18.00 & 35.00 & 15.00 & 35.00 & 20.00 \\
\hline Moldova & 20.00 & 0.00 & 7.00 & 18.00 & 29.00 \\
\hline The Netherlands & 19.00 & 25.50 & 1.95 & 52.00 & 40.00 \\
\hline Norway & 25.00 & 28.00 & 9.00 & 12.00 & 21.90 \\
\hline Poland & 22.00 & 19.00 & 18.00 & 32.00 & 40.32 \\
\hline Portugal & 21.00 & 25.00 & 11.08 & 45.88 & 34.75 \\
\hline Romania & 19.00 & 16.00 & 16.00 & 16.00 & 44.00 \\
\hline Serbia & 18.00 & 10.00 & 12.00 & 12.00 & 35.80 \\
\hline Slovakia & 19.00 & 19.00 & 19.00 & 19.00 & 37.60 \\
\hline Slovenia & 20.00 & 20.00 & 16.00 & 41.00 & 38.20 \\
\hline Spain & 18.00 & 30.00 & 24.00 & 43.00 & 37.33 \\
\hline Sweden & 25.00 & 26.30 & 31.00 & 57.77 & 30.43 \\
\hline Switzerland & 8.00 & 8.50 & 0.77 & 11.50 & 26.20 \\
\hline Ukraine & 20.00 & 19.00 & 15.00 & 17.00 & 39.15 \\
\hline The United Kingdom & 17.50 & 28.00 & 20.00 & 50.00 & 23.80 \\
\hline Turkey & 18.00 & 20.00 & 15.00 & 35.00 & 17.00 \\
\hline
\end{tabular}

To group the countries, two methods have been used that allow for hierarchical and non-hierarchical clustering to obtain the most qualitative distribution. Non-hierarchical clustering was carried out by the k-means method, the characteristic feature of which is the need to specify the number of clusters by which the grouping is performed (as a rule, the number of clusters is set on the basis of previously formulated hypotheses). The evaluation was carried out using the software Statistica 6.0. Given the significant number of countries that were included in the sample, it was advisable to test a different number of cluster centers in order to maximize the objectivity of the distribution results, since the formulation of hypotheses in this case could lead to artificial distortion of results. Therefore, to determine the most qualitative clustering, we estimate the results of the variance analysis for a different number of clusters (Table 3).

Table 3. Results of variance analysis for different clustering options in European countries on the structure of tax systems

\begin{tabular}{|c|c|c|c|c|c|}
\hline \multirow{2}{*}{ Criteria of variance analysis } & \multicolumn{5}{|c|}{ Variables } \\
\hline & $V A T$ & $C I T$ & $T P I_{\min }$ & $T P I_{\max }$ & $S I$ \\
\hline \multicolumn{6}{|c|}{2 clusters } \\
\hline Intergroup variance & 22.329 & 721.635 & 13.756 & 5759.471 & 90.059 \\
\hline Intra-group variance & 331.941 & 1399.068 & 1729.271 & 1642.259 & 4473.183 \\
\hline Abnormality of factorial sign $p$ & 0.134 & 0.000 & 0.601 & 0.000 & 0.407 \\
\hline \multicolumn{6}{|c|}{3 clusters } \\
\hline Intergroup variance & 14.622 & 706.378 & 132.231 & 5406.038 & 2870.521 \\
\hline Intra-group variance & 339.648 & 1414.325 & 1610.797 & 1995.692 & 1692.722 \\
\hline Abnormality of factorial sign $p$ & 0.488 & 0.001 & 0.262 & 0.000 & 0.000 \\
\hline \multicolumn{6}{|c|}{4 clusters } \\
\hline Intergroup variance & 35.775 & 875.024 & 163.046 & 6072.349 & 3050.806 \\
\hline Intra-group variance & 318.495 & 1245.679 & 1579.981 & 1329.381 & 1512.437 \\
\hline Abnormality of factorial sign $p$ & 0.000 & 0.000 & 0.019 & 0.000 & 0.000 \\
\hline \multicolumn{6}{|c|}{5 clusters } \\
\hline Intergroup variance & 41.201 & 918.357 & 579.479 & 6081.580 & 3085.786 \\
\hline Intra-group variance & 313.070 & 1202.345 & 1163.548 & 1320.150 & 1477.456 \\
\hline Abnormality of factorial sign $p$ & 0.000 & 0.000 & 0.002 & 0.000 & 0.000 \\
\hline
\end{tabular}

Note that improving the quality of the cluster distribution illustrates the increase in the values of the intergroup variance and the decrease in the values of the intra-group variance, while the abnormality level of the factor 
sign should not exceed 0.05 units achieved when countries are divided into 4 clusters, 5 clusters make it possible to achieve further improvements in the values of intra-group and intergroup variance, however, leads to a complication in the interpretation of the characteristics of the clusters obtained, since the coordinates of the cluster centers differ little from each other.

To further verify the adequacy of the results, we also perform hierarchical clustering by the Ward method using the Stata 12.0 software. The results of clustering are shown in Figure 1.

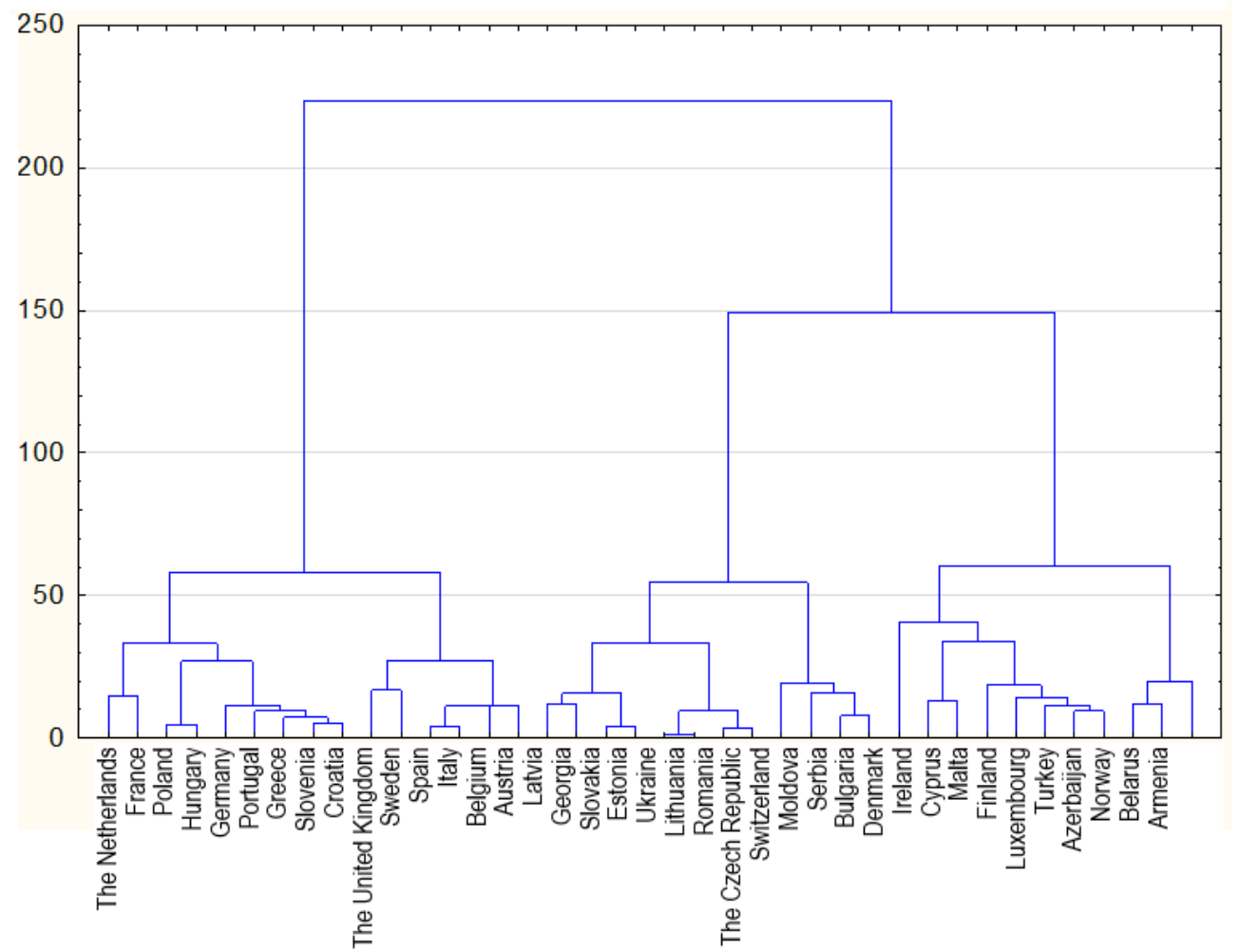

Figure 1. The results of clustering of European countries in the structure of tax systems by the Ward method

The mathematical toolkit of the Stata 12.0 software used in applying this clustering method also allows identifying the optimal number of clusters at which the most qualitative hierarchical structure of the grouping of research objects is achieved. The estimation of optimal number of clusters in this approach can be performed based on the Kalinsky-Kharabash index, which is calculated for each cluster solution - in this case for each level of the hierarchy. The maximum value of the index illustrates the clearest clustering (Table 4).

Table 4. Results of verification of clustering quality by the Kalinski-Kharabash index

\begin{tabular}{|c|c|}
\hline Number of clusters & Kalinski-Kharabash index \\
\hline 2 & 19.29 \\
\hline 3 & 21.94 \\
\hline 4 & 17.85 \\
\hline 5 & 17.59 \\
\hline 6 & 17.52 \\
\hline 7 & 17.57 \\
\hline 8 & 18.22 \\
\hline 9 & 17.70 \\
\hline 10 & 18.47 \\
\hline
\end{tabular}

Analyzing the results, we note that the most qualitative distribution is characteristic for the formation of three clusters. Given the hierarchical links shown in Figure 1, the distribution of countries by clusters can be carried out as follows (Table 5).

Table 5. Cluster distribution of European countries by the structure of the tax system as a result of applying the Ward method 


\begin{tabular}{|c|c|c|}
\hline Cluster 1 & Cluster 2 & Cluster 3 \\
\hline Armenia, Belarus, Norway, \\
$\begin{array}{c}\text { Turkey, Cyprus, Denmark, Finland, } \\
\text { Ireland, Turkey, Luxembourg, } \\
\text { Malta }\end{array}$ & $\begin{array}{c}\text { Austria, Belgium, Croatia, France, Germany, } \\
\text { Greece, Hungary, Italy, the Netherlands, } \\
\text { Poland, Portugal, Slovenia, Spain, Sweden, the } \\
\text { United Kingdom }\end{array}$ & $\begin{array}{c}\text { Bulgaria, the Czech Republic, Estonia, } \\
\text { Georgia, Latvia, Lithuania, Moldova, } \\
\text { Romania, Serbia, Slovakia, Switzerland, } \\
\text { Ukraine }\end{array}$ \\
\hline
\end{tabular}

Comparison of clustering results obtained by different methods shows that the list of countries included in clusters 2 and 3 according to the Ward method, identical to the sets of countries, forming clusters 2 and 3 , allocation by the k-means method, while cluster 1 is constructed by the method Ward, unites countries belonging to clusters 1 and 4, formed by the k-means method. Taking into account received results, the final distribution of European countries in the structure of the tax system allowed to form three clusters of tax competitors:

Cluster 1 "Potential competitors for labor" - countries with a moderate level of taxation in proportion to existing structure of the tax system, the moderate progressiveness of the system of taxation of personal incomes and low level of social contributions.

Cluster 2 "Potential competitors for the choice of the place of residence" - a country in which there is a significant level of tax, high progressive system of taxation of income of individuals, a significant shift of the tax burden on individuals.

Cluster 3 "Potential competitors for capital" - a country characterized by low taxation, insignificant progressive system of taxation of income of individuals, however, with a significant level of social contributions.

The observed clusters of countries are characterized by specific features, not only in terms of the structural construction of the tax system, but also by the participation in tax competition. Thus, the countries of the first and third clusters of tax competition are mainly short-term in terms of the placement of the objects of taxation. The aim of the taxpayers in the choice of jurisdiction in these clusters is to obtain additional income by reducing the amounts of taxes paid. Consequently, the generation of additional income, which can be disposed of by individuals for personal use (cluster 1 ) or to achieve short-term competitive advantages by saving costs of business (cluster 3). At the same time, cluster 2 includes countries that are characterized by a significantly higher level of development and, therefore, the welfare of their citizens and better business conditions. This indicates significantly different level of tax competition - taxpayers make decisions, given the level of public goods (for individuals) or the level of infrastructure support business (for legal entities), which they receive because of the payment of a larger tax amount.

Thus, as a result of the first stage of clustering, it was found that the tax system of Ukraine is characterized by the presence of common features with the tax systems of Bulgaria, the Czech Republic, Estonia, Georgia, Latvia, Lithuania, Moldova, Romania, Serbia, Slovakia and Switzerland. These countries have the lowest level of taxation for the most groups of taxes among the entire sample of the countries studied, namely for taxes paid by corporations. This creates grounds for asserting that capital is the main object of tax competition in this cluster. The group of these countries is the object of further research in the process of identifying countries - real tax competitors in Ukraine.

The second stage of clustering is the definition of real tax competitors in clusters with a similar structure of tax systems in terms of the level of socio-economic development. The goal of this stage is the differentiation of countries - potential tax competitors by the proximity degree of their socio-economic development. At this stage of the study the following criteria were selected by factorial signs: the level of gross domestic product, mln. USD; Consumer price index (price level in $2010=100$ ); Annual growth rate of GDP, \%; Net national income per capita at purchasing power parity, mln. USD.

These indicators allow considering the overall level of development of the country, which, of course, is important in the process of decision-making by taxpayers on the placement of taxable items, especially in the case of a choice between jurisdictions with similar taxation conditions. The statistical information source for the calculations is the World Bank statistical database [9]; the data are presented in Table 6. 
Table 6. Indicators characterizing the level of socio-economic development in Europe as of 2013

\begin{tabular}{|c|c|c|c|c|}
\hline Country & $\begin{array}{c}\text { The level of GDP, } \\
\text { mln. USD }\end{array}$ & $\begin{array}{l}\text { The annual } \\
\text { rate of GDP } \\
\text { growth, } \%\end{array}$ & $\begin{array}{l}\text { Consumer price index } \\
\quad(2010 \text { year }=100)\end{array}$ & $\begin{array}{l}\text { Net national income per capita at } \\
\text { purchasing power parity, mln. USD }\end{array}$ \\
\hline Armenia & 10431.22 & 3.50 & 116.80 & 8180.00 \\
\hline Austria & 428321.94 & 0.23 & 107.95 & 45040.00 \\
\hline Azerbaijan & 73560.48 & 5.80 & 111.54 & 16180.00 \\
\hline Belarus & 73097.62 & 1.07 & 288.65 & 17000.00 \\
\hline Belgium & 524778.84 & 0.29 & 107.66 & 41160.00 \\
\hline Bulgaria & 54479.87 & 1.10 & 108.30 & 4595.50 \\
\hline Croatia & 57868.67 & -0.94 & 108.08 & 20890.00 \\
\hline Cyprus & 24057.25 & -5.36 & 105.33 & 30240.00 \\
\hline The Czech Republic & 208796.02 & -0.71 & 106.80 & 13648.70 \\
\hline Denmark & 335877.55 & -0.49 & 106.06 & 45350.00 \\
\hline Estonia & 24880.26 & 1.62 & 112.20 & 11750.10 \\
\hline Finland & 268196.96 & -1.32 & 107.89 & 40000.00 \\
\hline France & 2810249.22 & 0.66 & 105.01 & 38200.00 \\
\hline Georgia & 16140.05 & 3.31 & 107.02 & 2119.10 \\
\hline Germany & 3730260.57 & 0.11 & 105.69 & 45020.00 \\
\hline Greece & 242230.73 & -3.90 & 103.92 & 25660.00 \\
\hline Hungary & 133423.90 & 1.53 & 111.79 & 22660.00 \\
\hline Ireland & 232077.37 & 0.17 & 104.84 & 38860.00 \\
\hline Italy & 2136948.26 & -1.70 & 107.16 & 35000.00 \\
\hline Latvia & 30908.76 & 4.23 & 106.71 & 9603.30 \\
\hline Lithuania & 46403.19 & 3.31 & 108.52 & 10306.90 \\
\hline Luxembourg & 60130.85 & 1.99 & 108.01 & 57830.00 \\
\hline Malta & 9642.85 & 2.90 & 106.65 & 27020.00 \\
\hline Moldova & 7985.35 & 9.41 & 117.82 & 1258.60 \\
\hline The Netherlands & 853539.35 & -0.73 & 107.47 & 46260.00 \\
\hline Norway & 522349.11 & 0.74 & 104.19 & 66520.00 \\
\hline Poland & 526064.04 & 1.71 & 109.08 & 23160.00 \\
\hline Portugal & 224912.48 & -1.60 & 106.82 & 27240.00 \\
\hline Romania & 189639.11 & 3.54 & 113.70 & 5864.70 \\
\hline Serbia & 45519.65 & 2.63 & 128.51 & 4122.00 \\
\hline Slovakia & 97712.68 & 1.42 & 109.23 & 15092.20 \\
\hline Slovenia & 47989.86 & -1.00 & 106.29 & 28650.00 \\
\hline Spain & 1393040.18 & -1.23 & 107.21 & 32860.00 \\
\hline Sweden & 579526.01 & 1.28 & 103.83 & 46260.00 \\
\hline Switzerland & 685434.21 & 1.93 & 99.31 & 59710.10 \\
\hline Ukraine & 183310.15 & 0.01 & 108.33 & 2059.50 \\
\hline The United Kingdom & 2678173.49 & 1.66 & 110.18 & 37900.00 \\
\hline Turkey & 823242.59 & 4.20 & 124.6 & 7862.00 \\
\hline
\end{tabular}

At this stage, the Ward's hierarchical clustering method was applied, according to which, firstly, clusters are formed, which include one country, allows to identify the proximity degree of factor characteristics in the context of individual countries. Given the different dimensions of the criteria being evaluated, the standardization of data was carried out before the hierarchical analysis, which allowed them to be distributed in the range $(-3 ; 3)$.

Based on the calculations, we can draw the following conclusions regarding the choice of countries whose tax policy should be taken into account when establishing a strategy for the development of Ukrainian tax competitiveness: 
$>$ considering a similar level of socio-economic development, Bulgaria is the most real tax competitor of Ukraine. At the same time, it should be noted that Latvia and Lithuania, Estonia and Slovakia, as well as Moldova and Serbia compete within this cluster to the greatest extent;

$>$ similar level of socio-economic development in comparison with Ukraine and Bulgaria is demonstrated by Georgia, which allows attributing it to the type of possible tax competitors in Ukraine. At the same time, among the countries being evaluated, it should be noted that Romania has similar features with Latvia and Lithuania in terms of socio-economic development indicators, and the Czech Republic can compete with Estonia and Slovakia for the placement of funds;

$>$ considering the third level of association that indicates the substantial differences of socio-economic development, Latvia, Lithuania and Romania are potential tax competitors of Ukraine;

$>$ despite very significant differences in socio-economic development, the Czech Republic, Estonia and Slovakia can be considered as promising tax competitors of Ukraine, the tax competition with which will become real in conditions of achieving favorable trends in socio-economic development of domestic economy;

$>$ dislocated tax competitors of Ukraine and other specified countries are Serbia and Moldova, for which it is possible to ascertain the various stages of socio-economic development, which has a significant impact on the decisions of taxpayers;

$>$ the latent tax competitor of Ukraine is Switzerland, for which a fundamentally different level of socioeconomic development is characteristic in comparison with the economies of other countries that have fallen into this cluster.

Taking into account the obtained results, we consider it expedient to further exclude Switzerland from being part of Ukraine's real tax competitors, since the similarity of the tax system in this case does not matter when the taxpayers make decisions, given the fact that Switzerland in most studies is classified as offshore zone considering the specifics of the functioning of its banking system.

So, on the whole, a methodical approach to the definition of Ukraine's tax competitors in the European tax space has been developed and the results of its practical application can be presented in Figure 2 (see in Appendix).

Subsequent to the results of evaluation it has been established that a group of real tax competitors of Ukraine among the European countries consists of 10 countries (Bulgaria, Georgia, Latvia, Lithuania, Romania, the Czech Republic, Estonia, Slovakia, Moldova and Serbia), which forms the basis for further research to assess the direction of trends in the development of these countries, tax systems in the context of identifying the problems and prospects of the functioning of the domestic tax system in terms of its tax competitiveness and the development of proposals for reform based on the vector of development of the tax systems of its main tax competitors.

\section{Conclusions}

In the context of reforming the tax system of Ukraine in terms of tax competition, the definition of a clear circle of countries - its tax competitors - is of particular importance. For this purpose, a cluster analysis of 38 European countries on the criteria of the structure of the country's tax system and the level of its social and economic development was carried out. The most real tax competitor for Ukraine is Bulgaria, because both the structure of its tax system and the level of socio-economic development are most closely approximated to Ukraine. Since Switzerland is a latent tax competitor of Ukraine, it is fundamentally different in terms of socio-economic development, its further study from the point of view of tax competition is considered inexpedient. Ukraine belongs to a cluster of countries with a low level of taxation, insignificant progressiveness of the system of taxation of incomes of individuals, a significant level of social contributions.

\section{References}

1. Blöchliger, H., Pinero-Campos, J. (2011). Tax Competition Between Sub-Central Governments. OECD Network on Fiscal Relations across Levels of Government Working Paper, 13, 45 p.

2. Collecting Taxes [Electronic source]. USAID Database. Retrieved from https://egateg.usaid.gov/ collecting-taxes/.

3. Delgado, F.J. (2013). Are Taxes Converging in Europe? Trends and Some Insights into the Effects of Economic Crisis. Journal of Global Economics, 1(1), 24-26. 
4. Fernandez, G. (2002). Strategic Tax Competition with a Mobile Population. Retrieved from http://www.depeco.econo.unlp.edu.ar/semi/semi050402.pdf.

5. Gordon, R., Wilson, G. (2002). Expenditure Competition. Retrieved from http://www.econ.ucsd.edu/ rogordon/zoning6.pdf.

6. Kemp, M. (1961). Foreign Investment and National Advantage. The Economic Record, 28, 56-62.

7. MacDougall, G. (1960). The benefits and Costs of Private Investments from Abroad: A Theoretical Approach. Economic Record, 36, 13-35.

8. Richman, P. (1963). Taxation of Foreign Investment Income. Baltimore: Johns Hopkins Press, 140 p.

9. The World Bank: official web-page [Electronic resource]. Retrieved from http://data.worldbank.org/indicator.

10.Tiebout, C. (1956). A Pure Theory of Local Expenditures. Journal of Political Economy, 64(5), 416-424.

11.Wildasin, D. (2011). Fiscal Competition for Imperfectly-Mobile Labor and Capital: A Comparative Dynamic Analysis. Journal of Public Economics, 95(11-12), 1312-1321.

12.Zodrow, G., Mieszkowski, P. (1986). Pigou, Tiebout, property taxation and the underprovision of local public goods. Journal of Urban Economics, 19, 356-370. 